\title{
Evaluasi Kinerja Sistem Manajemen Keselamatan dan Kesehatan Kerja (SMK3) Pada Proyek Attic Showroom dan East Coast Center 2 Di Surabaya
}

\author{
Juliandres Unitly ${ }^{1,}$ Feri Harianto ${ }^{2}$ dan Dian Listyaningsih ${ }^{3}$ \\ ${ }^{1,2}$ Jurusan Teknik Sipil, Fakultas Teknik Sipil dan Perencanaan,ITATS, Surabaya \\ E-mail: julianandrewunitly@gmail.com ${ }^{1}$,gokbio@yahoo.com ${ }^{2}$,dianlistyaningsih@itats.ac.id ${ }^{3}$
}

\begin{abstract}
ABSTRAK: Sektor konstruksi adalah salah satu sektor yang paling beresiko terhadap kecelakaan tenaga kerja, kerugian jiwa, material, uang, dan waktu merupakan akibat-akibat yang tentu saja akan menghambat secara langsung pelaksanaan proyek konstruksi. Untuk mencegah kecelakaan pada pelaksanaan pekerjaan konstruksi diwajibkan untuk menerapkan Sistem Manajemen Keselamatan Dan Kesehatan Kerja (SMK3) di lokasi kerja. Oleh karena itu penelitian ini bertujuan untuk mengetahui pelaksanaan penerapan Sistem Manajemen Keselamatan Dan Kesehatan Kerja (SMK3) dan perbedaan kinerja pada proyek konstruksi yang ada di kota surabaya. Penelitian ini menggunakan metode Fisher Exact Probability dengan pengambilan data yang dilakukan melalui kuesioner yang telah dibagikan kepada masingmasing responden sesuai kriteria yang telah ditentukan pada proyek yang diteliti. hasil dari penelitian ini berdasarkan Peraturan Mentri Tenaga Kerja (permenaker) no.5 tahun 1996, untuk Proyek Attic Showroom Dharmahusada nilai ratarata pencapaian adalah 76,74\% dengan predikat baik, dan Proyek East Coast Center 2 nilai rata-rata pencapaian 84,92\% dengan predikat memuaskan. Sedangkan perbandingan antara kedua proyek berdasarkan setiap poin pertanyaan menunjukan perbedaan yang signifikan diukur dari 12 kriteria audit Sistem Manajemen Keselamatan dan Kesehatan Kerja (SMK3) menurut permenaker no.50 tahun 1996 terdapat 8 item yang memiliki perberbedaan yang signifikan dan 4 item yaitu pada poin Pembangunan dan Pemeliharaan Komitmen, poin Pembuatan dan Pendokumentasian K3, poin keamanan bekerja berdasarkan SMK3, serta pada poin Pelaporan dan Perbaikan Kekurangan tidak terdapat perbedaan yang signifikan.
\end{abstract}

Kata Kunci : keselamatan, kesehatan, manajemen k3, perbandingan, SMK3

\section{PENDAHULUAN}

Industri konstruksi adalah industri yang paling beresiko terhadap kecelakaan tenaga kerja, Kecelakaan kerja yang terjadi pada proyek konstruksi menjadi salah satu penyebab terganggunya atau terhentinya aktivitas pekerjaan proyek. oleh karena itu, pada saat pelaksanaan pekerjaan konstruksi diwajibkan untuk menerapkan Sistem Manajemen Keselamatan dan Kesehatan Kerja (SMK3) dilokasi kerja dimana masalah keselamatan dan kesehatan kerja ini juga merupakan bagian dari perencanaan dan pengendalian proyek. Dengan demikian perusahaan akan semakin diuntungkan dalam upaya pencapaian tujuannya Untuk mencegah kecelakaan pada pelaksanaan pekerjaan (Harianto, 2015)

Permasalahan sistem manajemen keselamatan dan kesehatan kerja (SMK3) secara umum di Indonesia masih saja terabaikan, karena hal ini ditunjukkan dengan masih tingginya angka kecelakaan kerja yang terjadi pada proyek konstruksi.

Sesuai dengan data Badan Penyelenggara Jaminan Sosial (BPJS) Ketenagakerjaan, sampai akhir 2015 telah terjadi kecelakaan kerja sebanyak 105.182, untuk kasus kecelakaan berat yang mengakibatkan kematian tercatat sebanyak 2.375 kasus dari total jumlah kecelakaan kerja, dan cenderung terus meningkat sebanyak 123.000 kasus kecelakaan kerja tercatat sepanjang tahun 2017. Kondisi inilah mencerminkan kesiapan daya saing perusahaan Indonesia di dunia internasional masih sangat minim. Indonesia akan mengalami kesulitan menghadapi pasar global karena mengalami ketidakefisienan penyerapan tenaga kerja (produktivitas tenaga kerja yang rendah).

Sistem manajemen keselamatan dan kesehatan kerja merupakan aspek penting dalam usaha meningkatkan kesejahteraan serta produktivitas karyawan. Apabila tingkat keselamatan kerja sangat tinggi, maka kecelakaan yang menyebabkan sakit, cacat, dan kematian dapat ditekan sekecil mungkin. Apabila keselamatan kerja rendah, maka hal tersebut akan berpengaruh buruk terhadap kesehatan sehingga berakibat pada produktivitas yang menurun (Hariandja, 2013).

Keberhasilan penerapan keselamatan dan kesehatan kerja dalam suatu proyek dapat dilihat dari tingkat pencapaian nilai ukur menurut standar nilai yang tertulis dalam suatu peraturan pemerintah. Penelitian ini akan mengevaluasi bagaimana keberhasilan penerapan dan pelaksanaan Sistem Manajemen Keselamatan dan Kesehatan Kerja (SMK3) pada beberapa proyek pembangunan yang ada di Surabaya dilihat dari tingkat keberhasilan penerapannya. Tujuan penelitian ini adalah untuk Mengetahui Pelaksanaan Penerapan Sistem Manajemen Keselamatan dan Kesehatan Kerja (SMK3) Pada Proyek Kontruksi dan Perbedaan Kinerja Sistem Manajemen Keselamatan dan Kesehatan Kerja (SMK3) Pada Proyek Konstruksi.

\section{LANDASAN TEORI}

Pengertian keselamatan dan kesehatan kerja (K3)

Keselamatan dan kesehatan kerja (K3) adalah segala kegiatan untuk menjamin. Menghindari dan melindungi keselamatan dan kesehatan tenaga kerja melalui upadaya pencegahan kecelakaan kerja dan penyakit akibat kerja.

Keselamatan dan kesehatan kerja ialah rangkaian upaya dan usaha untuk dapat menciptakan suasana yang aman dan tentram bagi para karyawan yang bekerja pada perusahaan tersebut (Suma'mur, 2001).

\section{Keselamatan kerja}

Keselamatan kerja adalah upaya utama untuk pencegahan kecelakaan, cacat bahkan sampai pada kematian sebagai akibat kecelakaan kerja. Keselamatan kerja yang sangat baik adalah pintu gerbang bagi keamanan para pekerja, keselamatan kerja berhubungan 
dengan semua proses produksi dan distribusi, baik barang maupun jasa (Suma'mur, 2001).

Adapun sasaran pada keselamatan kerja secara terinci yaitu:

a) Mencegah terjadinya kecelakaan di lingkungan kerja

b) Mencegah timbulnya sebuah penyakit akibat kerja

c) Mencegah/mengurangi kematian akibat kerja

d) Mencegah atau mengurangi cacat tetap.

e) Mengamankan material-material, konstruksi, pemakaian, pemilihan bangunan-bangunan, alat-alat kerja, mesin-mesin, instalasi-instalasi.

f) Meningkatkan produktivitas kerja tanpa memeras tenaga kerja dan menjamin setiap kehidupan produktifnya.

g) Mencegah pemborosan bagi tenaga kerja, modal, peralatan dan sumber produksi lainnya sewaktu kerja.

h) Menjamin lingkungan kerja yang sehat, bersih, nyaman dan aman sehingga dapat menimbulkan kegembiraan dan semangat bagi pekerja.

i) Memperlancar dan mengamankan produksi, industri serta bangunan.

Semuanya itu menuju pada sebuah peningkatan taraf hidup dan kesejahteraan umat manusia (Endroyo, 1989).

\section{Kesehatan kerja}

Kesehatan kerja adalah sebuah kondisi badan/tubuh yang terlindungi dan terhindar dari segala macam penyakit atau gangguan yang diakibatkan oleh pekerjaan yang dilaksanakan.

\section{Kecelakaan kerja}

Kecelakaan adalah kejadian yang tidak diharapkan, tidak diinginkan, tidak diramalkan, tidak direncanakan, tidak terduga serta tidak ada unsur kesengajaan yang dapat mengganggu atau merusak kelangsungan yang wajar dari suatu kegiatan dan dapat mengakibatkan suatu luka atau kerusakan pada benda atau peralatan (Sudinarto, 1995).

\section{Tujuan dan Manfaat K3}

Tujuan Keselamatan dan Kesehatan Kerja:

1. Melindungi para pekerja atas hak keselamatan dalam melakukan pekerjaan untuk kesejahteraan hidup.

2. Menjamin keselamatan setiap orang lain yang berada di lingkungan kerja.

3. Sumber produksi dipelihara dan dipergunakan secara baik, aman dan efisien

Manfaat Keselamatan dan Kesehatan Kerja (K3) Secara Ekonomi (Husen, 2011):

1. Menghemat biaya yang tak terduga.

2. Menambah moral dan produktivitas kerja.

3. Mengurangi resiko dan menghemat biaya asuransi pekerja

4. Premiumnya lebih rendah akibat kecelakaan perusahaan yang rendah.

5. Nama dan reputasi yang baik bagi perusahaan dalam hal keselamatan dan kesehatan kerja dapat meningkatkan permintaan pasar terhadap perusahaan.

\section{Sistem Manajemen Keselamatan \& Kesehatan Kerja}

Sistem Manajemen keselamatan dan kesehatan kerja (SMK3) adalah bagian dari sistem manajemen perusahaan secara keseluruhan dalam rangka pengendalian resiko yang berkaitan dengan kegiatan kerja guna terciptanya tempat kerja yang aman dan produktif.

Pengelolaan K3 dapat berjalan dengan baik karena mengikuti tujuan manajemen yang baik, yaitu dimulai dengan proses perencanaan, kemudian penerapan yang didukung oleh sistem pengukuran dan pemantauan dan terakhir dilakukan tinjau ulang secara berkala untuk memperbaiki proses secara berkesinambungan. Bayangkan saja ada perusahaan yang menerapkan K3 tanpa sistem dan bandingkan dengan perusahaan yang menerapkan K3 dengan sistem. Hasilnya pasti akan berbeda

Menurut Permenaker No. 5 tahun 1996, Penerapan SMK3 bertujan untuk:

a. Meningkatkan perlindungan keselamatan dan kesehatan kerja yang terencana, terukur, terstruktur, dan terintregasi

b. Mencegah kecelakaan saat kerja dan penyakit akibat kerja dengan melibatkan unsur manajemen, pekerja/buruh, dan/ serikat pekerja,serikat buruh; serta

c. Menciptakan tempat kerja yang aman, nyaman, bagi tenaga kerja dan efisien untuk mendorong produktifitas,

Adapun elemen sistem dalam menerapkan SMK3 setiap perusahaan wajib melaksanakan :

A. Penetapan kebijakan K3

B. Perencanaan K3

C. Pelaksanaan rencana $\mathrm{K} 3$

\section{METODE PENELITIAN}

Penelitian ini menggunakan teknik pengumpulan data yang dilakukan dengan observasi dan untuk pengambilan sampel di lapangan dilakukan secara purposive. Pengambilan sampel secara purposive adalah cara penarikan sampel yang dilakukan memilih subjek berdasarkan kriteria spesifik yang ditetapkan peneliti.

Penelitian ini dilaksanakan di Kota Surabaya yang merupakan salah satu kota berkembang di Indonesia, tepatnya pada 2 proyek berbeda. Proyek pertama yaitu East Coast Center 2 yang dan proyek yang kedua yaitu Attic Showroom Dharmahusada.

Penelitian ini menggunakan 2 metode sebagai berikut:

1) Kuesioner jenis check list dengan metode skala Guttman, yaitu kuesioner jenis check-list yang menggunakan jawaban bersifat jelas, tegas, dan konsisten, seperti: ya - tidak, sesuai - tidak sesuai, benar - salah, positif - negatif, dan lain sebagainya (Riduwan, 2003). Kuesioner berisi 166 poin pertanyaan mengenai Sistem Manajemen K3 mengacu pada pedoman daftar periksa audit penilaian Penerapan Sistem Manajemen K3 Permenaker nomor 5 tahun 1996 dengan jawaban "sesuai" dan "tidak sesuai”. Kriteria pencapian penerapan seperti pada Tabel 1.

2) Metode yang digunakan dalam penelitian ini adalah metode Fisher exact probability test. Test ini digunakan untuk menguji signifikansi hipotesis komparatif dua sampel kecil independent bila datanya berbentuk nominal untuk sampel yang besar digunakan chi kuadrat $\left(\chi^{2}\right)$. Untuk memudahkan 
perhitungan dalam pengujian hipotesis, maka data hasil pengamatan perlu disusun kedalam Tabel 2 .

Tabel 1. Tingkat Pencapaian Penerapan SMK3

\begin{tabular}{|c|c|}
\hline \multicolumn{2}{|c|}{ Tingkat Pencapaian Penerapan } \\
\hline $0-59 \%$ & Kurang \\
\hline $60-84 \%$ & Baik \\
\hline $85-100 \%$ & Memuaskan \\
\hline
\end{tabular}

Tabel 2 Kontingensi $2 \times 2$

\begin{tabular}{|c|c|c|c|}
\hline Proyek & Sesuai & $\begin{array}{c}\text { Tidak } \\
\text { Sesuai }\end{array}$ & Jumlah \\
\hline I & A & B & A + B \\
\hline II & C & D & C + D \\
\hline \multicolumn{3}{|c|}{ Jumlah } & n \\
\hline
\end{tabular}

Rumus dasar yang digunakan adalah :

$p=\frac{(A+B) !(C+D) !(A+C) !(B+D)}{N ! A ! B ! C ! D !}$.

\section{Proyek I = Sampel I}

Proyek II = Sampel II

Proyek sesuai dan tidak sesuai hanya menunjukkan adanya klasifikasi, misalnya lulus atau tidak lulus, sesuai atau tidak sesuai.

$H 0$ : tidak ada perbedaan (sama)

$H 1$ : ada perbedaan (tidak sama)

$H 0$ diterima apabila nilai $\mathrm{p}$ lebih besar dari taraf kesalahan yang ditetapkan sebesar $\alpha: 0,05$

\section{HASIL PENELITIAN DAN PEMBAHASAN Profil Responden}

Data responden yang diambil adalah nama responden, nama instansi, pendidikan terakhir, jabatan dalam pekerjaan, dan lama bekerja. Responden didominasi lulusan Strata 1 (S1) dengan lama bekerja antara 1-15 tahun. Penjabaran dapat dilihat pada Gambar1,2, dan 3 :

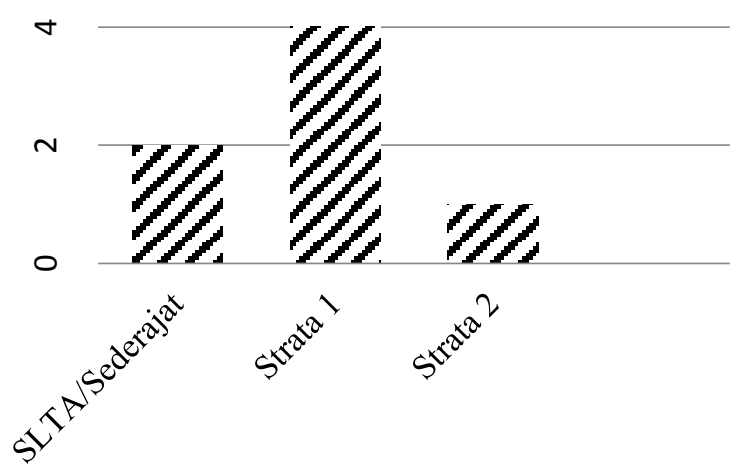

Gambar 1.Tingkat Pendidikan Responden $\checkmark$

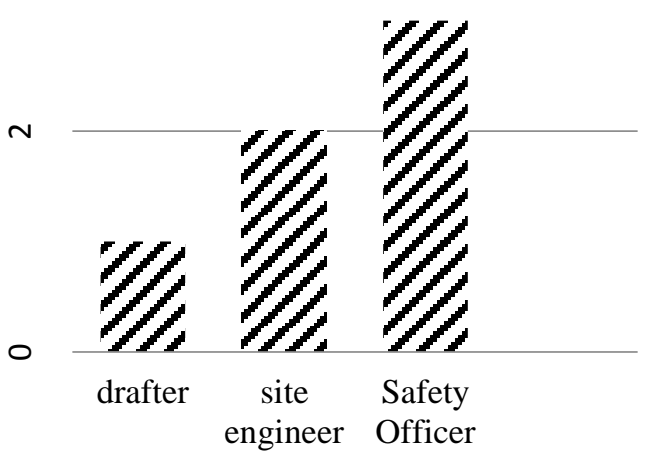

Gambar 2. Jabatan

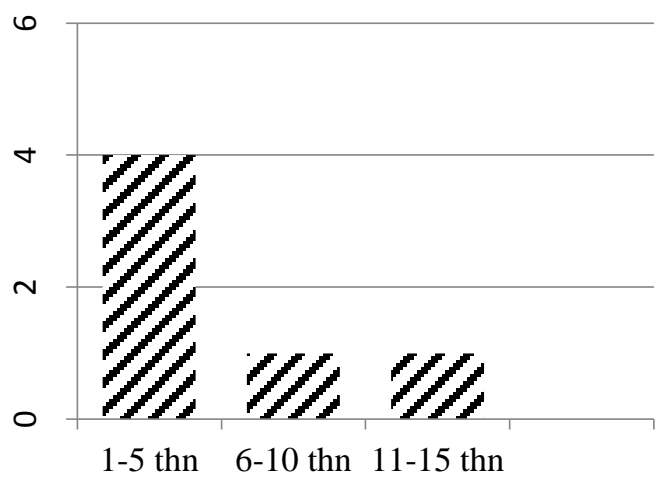

Gambar 3. Pengalaman Bekerja

\section{Evaluasi kinerja SMK3}

Penelitian dengan check list ini mengacu pada Permenaker no.5 tahun 1996 yang terdapat pada halaman lampiran total 166 kriteria. Perhitungan check list ini berdasarkan 12 kriteria induk menggunakan rumus :

\footnotetext{
$\frac{\Sigma \text { Nilai pemenuhan }}{166 \text { kriteria }}$ X $100 \%=$

Persentase Tingkat Pencapaian.
}

Dari hasil check list di 2 proyek yang ditinjau, dilakukan perhitungan tingkat penerapan sistem manajemen keselamatan dan kesehatan kerja berdasarkan hasil kuesioner yang di peroleh dari responden di masingmasing proyek. Hasil perhitungan dapat dilihat pada Gambar 4 dan 5:

Dari 3 responden pada proyek Attic Showroom didapat nilai rata-rata baik yaitu $76,74 \%$, namun ada beberapa ketidaksesuaian yang berpotensi dapat berdampak kurang baik bagi jalannya proyek. Adapun beberapa kriteria yang tidak sesuai dengan Peraturan Permenaker no.5 tahun 1996 yang sama dari ketiga responden tersebut, sebagai berikut :

- Tentang kebijakan SMK3 :

$>$ Keterlibatan dan penjadwalan konsultasi tenaga kerja dengan wakil perusahaan 
didokumentasikan dan disebarluaskan ke seluru tenaga kerja.

$>$ Dibentuk kelompok-kelompok kerja dan dipilih dari wakil-wakil tenaga kerja yang ditunjuk sebagai penanggung jawab K3 ditempat kerjanya dan kepadanya diberikan pelatihan sesuai dengan peraturan perundang-undangan.

$>$ Dibentuk kelompok-kelmpok kerja dan dipilih dari wakil-wakil tenaga kerja yang ditunjuk sebagai penanggung jawab K3 ditempat kerjanya dan diberikan pelatihan sesuai dengan perundang-undangan.

A. Proyek Attic Showroom Dharmahusada

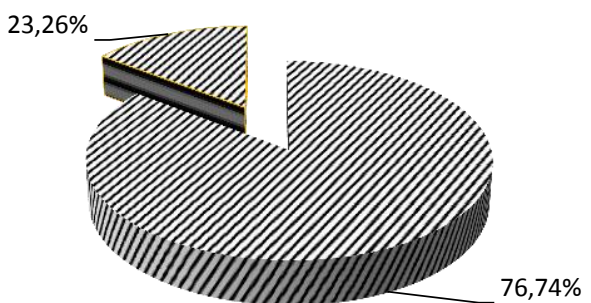

Gambar 4. Hasil Rata-Rata Kuesioner pada proyek Attick Showroom

- Tentang rencana strategi K3

$>$ Rencana strategi K3 sekurangkurangnya berdasarkan tinjauan awal, identifikasi potensi bahay, penilaian, pengendalian rasiko, dan peraturan perundang- undangan serta informasi K3 lain baik dari dalammaupun luar perusahan

$>$ Rencana strategi K3 yang telah ditetapkan digunakan untuk mengendalikan resiko $\mathrm{K} 3$ dengan menetapkan tujuan dan sasaran yang dapat diukur dan menjadi prioritas serta menyediakan sumber daya.

$>$ Rencana kerja dan rencana khusus yang berkaitan dengan produk, proses, proyek atau tempat kerja tertentu telah dibuat dengan menetapkan tujuan dan sasaran yang dapat diukur, menetapkan waktu pencapaian menyediakan sumber daya.

- Tentang pengendalian perancangan dan peninjauan kontrak

Petugas yang berkompeten melakukan verifikasi bahwa perancangan dan/atau modifikasi memenuhi persyaratan K3 yang ditetapkan sebelum penggunaan hasil rancangan.

$>$ Kontrak ditinjau ulang untuk penjamin bahwa pemasok dapat memenuhi persyaratan K3 bagi pelanggan.
B. Proyek East Coast Center 2

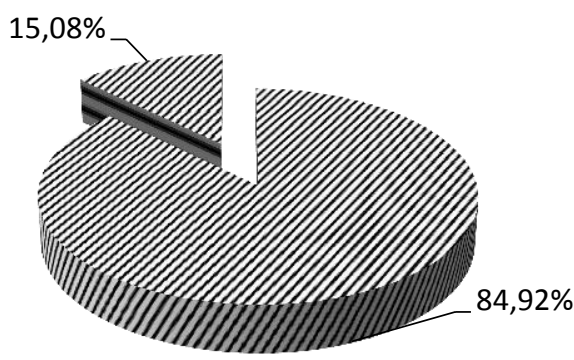

Gambar 5. Hasil Rata-Rata Kuesioner pada proyek East Coast Center 2

Dari 3 responden pada proyek East Coast Center 2 didapat nilai rata-rata memuaskan yaitu $90,56 \%$, namun ada beberapa ketidaksesuaian yang berpotensi dapat berdampak kurang baik bagi jalannya proyek. Adapun beberapa kriteria yang tidak sesuai dengan Permenaker no.5 tahun 1996 yang sama dari ketiga responden tersebut, sebagai berikut :

- Tentang tinjauan dan evaluasi :

> Tinjauan terhadap penerapan SMK3 meliputi kebijakan, perencanaan, pelaksanaan, pemantauan dan evaluasi telah dilakukan, dicatat dan didokumentasikan

$>$ Hasil tinjauan dimasukan dalam perencanaan tindakan manajemen

$>$ Pengurus harus meninjau ulang pelaksanaan SMK3 secara berkala

- $\quad$ Tentang manual SMK3 :

> Manual SMK3 meliputi kebijakan, tujuan, rencana, prosedur SMK3, instruksi kerja, formolir, catatan dan tanggung jawab K3 untuk semua tingkatan dalam perusahaan.

$>$ Terdapat manual khusus berkaitan dengan produk, proses, atau tempat kerja tertentu.

$>$ Manual SMK3 mudah didapat oleh semua personel dalam perusahaan sesuai kebutuhan.

- Tentang Rencana dan Pemulihan Keadaan Darurat

$>$ Prosedur dan pemulihan kondisi tenaga kerja maupun sarana dan peralatan dan peralatan produksi yang mengalami kerusakan telah ditetapkan dan dapat diterapkan sesegera mungkin setelah terjadinya kecelakaan dan penyakit akibat kerja.

- Tentang Pengendalian Bahan Kimia Berbahaya (BKB)

$>$ Perusahan telah mendokumentasikan dan menerapkan prosedur mengenai penyimpangan, penanganan dan pemindahan BKB sesuai dengan persyaratan peraturan perundang-undangan standart dan pedoman teknis yang relevan.

\section{Uji Fhiser Exact Probability}

Analisis Fhiser Exact Probability adalah analisis yang digunakan untuk mengetahui ada tidaknya perbedaan rata- 
rata dua sampel yang tidak berpasangan. Analisis ini merupakan bagian dari statistik non parametrik, sehingga tidak diperlukan data penelitian yang berdistribusi normal.

Adapun hasil analisis uji perbedaan menggunakan metode Fhiser Exact Probability dari 12 kriteria induk dari keusioner pada 2 proyek yang sudah diteliti seoerti pada Tabel 3.

Tabel 3. Uji perbedaan
Nyatakan Hipotesis :

$H 0$ : tidak ada perbedaan antara proyek A \& B (sama) $H 1$ : ada perbedaan antara proyek A \& B (tidak sama)

Taraf kesalahan yang ditetapkan sebesar $\alpha: 0,05$ Jika $\mathrm{p}$ hitung ( nilai fisher exact test) $<\alpha=H 0$ diterima Jika p hitung ( nilai fisher exact test) $>\alpha=H 1$ diterima

\begin{tabular}{|c|c|c|c|c|c|c|}
\hline \multirow[t]{3}{*}{ KRITERIA AUDIT SMK3 } & \multicolumn{4}{|c|}{ PENILAIAN } & \multirow{3}{*}{$\begin{array}{c}\text { Fisher } \\
\text { Exact } \\
\text { Probab } \\
\text { ility } \\
\text { Test }\end{array}$} & \multirow[t]{3}{*}{ KETERANGAN } \\
\hline & \multicolumn{2}{|c|}{ Proyek A } & \multicolumn{2}{|c|}{ Proyek B } & & \\
\hline & Sesuai & $\begin{array}{l}\text { Tidak } \\
\text { Sesuai }\end{array}$ & Sesuai & $\begin{array}{l}\text { Tidak } \\
\text { Sesuai }\end{array}$ & & \\
\hline $\begin{array}{l}\text { Pembangunan dan } \\
\text { Pemeliharaan Komitmen }\end{array}$ & $78,09 \%$ & $24,91 \%$ & $90,17 \%$ & $9,83 \%$ & 0,032 & $\begin{array}{l}\text { Tidak Terdapat } \\
\text { perbedaan }\end{array}$ \\
\hline $\begin{array}{l}\text { Pembuatan dan } \\
\text { Pendokumentasian Rencana } \\
\text { K3 }\end{array}$ & $50 \%$ & $50 \%$ & $77,76 \%$ & $22,24 \%$ & 0,018 & $\begin{array}{l}\text { Tidak Terdapat } \\
\text { perbedaan }\end{array}$ \\
\hline $\begin{array}{l}\text { Pengendalian Perancangan } \\
\text { dan Peninjauan Kontrak }\end{array}$ & $54,15 \%$ & $45,85 \%$ & $100 \%$ & $0 \%$ & 0,08 & Terdapat perbedaan \\
\hline Pengendalian dokumen & $68,07 \%$ & $31,93 \%$ & $100 \%$ & $0 \%$ & 0,06 & Terdapat perbedaan \\
\hline $\begin{array}{l}\text { Penilaian dan Pengendalian } \\
\text { Produk }\end{array}$ & $66,6 \%$ & $33,4 \%$ & $100 \%$ & $0 \%$ & 0,07 & Terdapat perbedaan \\
\hline $\begin{array}{l}\text { Keamanan Bekerja } \\
\text { Berdasarkan SMK3 }\end{array}$ & $83,32 \%$ & $16,68 \%$ & $83,32 \%$ & $16,68 \%$ & 0,026 & $\begin{array}{l}\text { Tidak Terdapat } \\
\text { perbedaan }\end{array}$ \\
\hline Standar Pemantauan & $85,71 \%$ & $14,29 \%$ & $100 \%$ & $0 \%$ & 0,07 & Terdapat perbedaan \\
\hline Pelaporan dan Perbaikan & $100 \%$ & $0 \%$ & $100 \%$ & $0 \%$ & 0,012 & $\begin{array}{c}\text { Tidak Terdapat } \\
\text { perbedaan }\end{array}$ \\
\hline $\begin{array}{l}\text { Pengelolahan material dan } \\
\text { perpindahannya }\end{array}$ & $53,28 \%$ & $46,72 \%$ & $40 \%$ & $60 \%$ & 0,06 & Terdapat perbedaan \\
\hline $\begin{array}{l}\text { Pengumpulan Dan } \\
\text { Penggunaan Data }\end{array}$ & $83,3 \%$ & $16,7 \%$ & $83,3 \%$ & $16,7 \%$ & 0,09 & Terdapat perbedaan \\
\hline Pemeriksaan SMK3 & $88,86 \%$ & $11,14 \%$ & $100 \%$ & $0 \%$ & 0,1 & Terdapat perbedaan \\
\hline $\begin{array}{l}\text { Pengembangan } \\
\text { Keterampilan dan } \\
\text { Kemampuan }\end{array}$ & $85,71 \%$ & $14,29 \%$ & $66,6 \%$ & $33,4 \%$ & 0,08 & Terdapat perbedaan \\
\hline
\end{tabular}

\section{UCAPAN TERIMAKASIH}

Terima kasih atas kerjasamanya dalam penelitian kepada pihak manajemen PT Mitra Konstruksi, dan PT Nusa Raya Cipta Tbk.

\section{KESIMPULAN DAN SARAN} Kesimpulan
1) Proyek konstuksi gedung yang diteliti sudah Menerapakan Sistem Manajemen Keselamtan dan Kesehatan Kerja dengan baik, akan tetapi sepenuhnya belum mencapai $100 \%$. Berdasarkan permenaker no.5 tahun 1996, untuk proyek Attic Showroom Dharmahusada dengan nilai rata-rata tingkat pencapaiannya adalah 76,74\%, kategori baik, sedangkan proyek East Coast Center 2 
mendapat nilai rata-rata tingkat pencapaian $84,92 \%$ kategori memuaskan.

2) Perbandingan antara kedua proyek yang diteliti berdasarkan perbandingan setiap poin pertanyaan menunjukan perbedaan signifikan diukur dari 12 kriteria audit SMK3 menurut Permenaker no.5 tahun 1996 terdapat 8 item yang memiliki perberbedaan yang signifikan dan 4 item yaitu pada poin pembangunan \& pemeliharaan komitmen, poin pembuatan dan pendokumentasian $\mathrm{K} 3$, poin keamanan bekerja berdasarkan SMK3, serta pada poin pelaporan \& perbaikan kekurangan tidak terdapat perbedaan yang signifikan.

\section{DAFTAR PUSTAKA}

Endroyo, Bambang. (1989). Keselamatan Kerja Untuk Teknik Bangunan. IKIP Semarang Press:Semarang.

Feri Harianto (2015). Evaluasi Penerapan Sistem Manajemen Keselamatan dan Kesehaan Kerja (SMK3) pada Proyek Pembangunan Apartemen Gunawangsa MERR Surabaya. SNTEKPAN 2015: $773-780$

Husein, Umar. (2011). Metode Penelitian Untuk Skripsi dan Tesis Bisnis Edisi 11. Jakarta: PT Raja Grafindo Persada

Kurniawan, Yanuar. (2011). Tingkat pelaksanaan Sistem Manajemen Keselamatan dan Kesehatan Kerja di Kota Semarang. Teknik Sipil, FTSP UNNES, Semarang.

Marihot, Tua Efendi Hariandja. (2013). Manajemen Sumber Daya Manusia dan Penikatan produktifitas Pegawai. Jakarta: Grafindo.

Peraturan Menteri Tenaga Kerja nomor 5 tahun 1996 tentang Sistem Manajemen Keselamatan dan Kesehatan Kerja. Jakarta: Menteri Tenaga Kerja Republik Indonesia.

Riduwan, (2003). Dasar-Dasar Statistika. Bandung:Alfabeta

Sugiyono. (2004). Statistik Nonparametris untuk Penelitian. Edisi Keempat: Bandung.

Suma'mur. (2001). Keselamatan Kerja dan Pencagahan Kelakaan. Jakarta:Gunung Agung.

Sudinarto, (1995). Manajemen Konstruksi Profesional, Erlangga, Jakarta. 